\title{
Gender Disparities in Water Resource Management Projects in Njoro Sub-County, Kenya
}

\author{
Wambu Charles K. ${ }^{1} \&$ Moses Kindiki ${ }^{1}$ \\ ${ }^{1}$ Department of Religion, Community development and Social Science, Masaai Mara University, Narok, Kenya. \\ Correspondence: Wambu Charles K., Department of Religion, Community development and Social Science, Masaai \\ Mara University, Narok, Kenya.
}

Received: November 26, 2014

Accepted: December 22, 2014

Available online: February 28, 2015

doi:10.11114/ijsss.v3i2.703

URL: http://dx.doi.org/10.11114/ijsss.v3i2.703

\begin{abstract}
Gender disparities are of major concern, in water resources management because men and women play different roles and have different rights on water usage and it is important to take in account the interest of both genders into account. Njoro Sub-county is currently facing a serious problem of water scarcity as a result of several factors such as poor management, loss of forest cover, climatic variability, population increase, and limited endowment of the resource. Water being an economic good and a cost attached to its development, distribution, operation and maintenance there has been gender disparity in its management. Women are responsible for multiple uses of water resources and principal decision-makers regarding domestic uses and sharing responsibility with men for productive uses. However men often control this resource and make major decisions related to location and type of facilities available hence the need to investigate why women despite their vital stake in water affairs, they are frequently overlooked and under-represented in water policy decisions and in water projects committees. The argument in this paper is that gender disparities may have resulted in overexploitation and mismanagement of water resources.
\end{abstract}

Keywords: gender disparities, water resources management, gender, equity

\section{Introduction}

Water crisis in Kenya is disrupting social-economic activities throughout the country. Unfortunately, the current wave of droughts and water shortages in Kenya is due to massive deforestation and environmental degradation making the problem of water shortage more severe (WEDO, 2003). The water shortage and crisis is not due to the wave of droughts, but also to poor management of the water supply, under-investment, rampant deforestation, and pollution of water sources by domestic and industrial effluents (WHO/UNICEF, 2004). Kenya is limited by an annual renewable fresh water supply of only 647 cubic meters per capita, and is classified as a water scarce country. Only $61 \%$ of the population in rural areas has access to an improved drinking water source, and time consuming venture of fetching water often prevents women from taking up income generating activities, or in the case of girls, prevents them from attending school or irregular attendance of school (Green and Baden, 1994). Water contributes to social well-being and economic growth of human populace. Most of the economic and social activities rely heavily on access to clean and adequate quality and quantity of water (WHO/UNICEF, 2004).

Although water supply is increasing following enhanced efforts for the millennium development goals (MDGs), there still are many women who carry water, their whole life, keeping them out of school and out of economic development and further empowerment (Vernooy,2006). "Promote gender equality and empower women", the third goal of the Millennium Development Goals (MDG) deals with equality between men and women in order to promote a better and sustainable development. Since the World Women Conference held in Beijing (1995), gender has been increasingly used in international conferences and declarations (Situma, 2000). It has been internationally accepted that promoting women's implication and status is key to a country development. Gender aspects do have the certain positive potential for improving water resources management and promoting efficiency of water use Njoro Sub-county has a serious problem of water scarcity as a result of factors such as poor management, loss of forest cover, climatic change, population increase, and limited endowment of the resource. Njoro Sub-county is served by one major river originating from Mau forest, several seasonal streams, under-ground water sources such as boreholes, and wells (Clever and Elson, 1995). Some of the water resources are drying up making the problem more serious. There are several water users' 
association projects which are aimed at supplying water in the rural households in the district and are experiencing poor management as a result of gender disparities. Water being an economic commodity and having a cost attached to its development, distribution; operation and maintenance have initiated interest by both genders (women and men) on its management (UNDP, 2002). In the Sub-county both women and men perform distinctive tasks in water management as a result of existing power relations and responsibility. The study employed Actors-Network Theory and Liberal Feminism Theory and descriptive survey research design. Proportionate sampling was used to determine the target sample in which stratified random sampling was used to sample one hundred and twenty households and twenty-one water projects in four divisions to form the target sample size. The divisions were purposively sampled because this is where wide spread scarcity and gradual destruction of these resource was common. Structured interview schedule was administered orally to the sampled households. In Kenya efforts have been made towards addressing gender issues through enactment of the Constitution and Millennium Development Goals (DFID, 2002). However, a discrepancy exists between men and women, in access, uses and management of water. In Njoro sub-county gender disparities in water sector have persisted mainly because in some cases the attitudes of water users towards women have not changed to accommodate women. In some cases even the official state policy on water has not changed to reflect the changes in perception on gender. Where policies have changed to reflect gender needs and practices at the water user level, still gender practices have lagged behind and this affects women.

This paper examined factors affecting gender participation in planning and implementation of water resource projects and analyzed gender contribution in co-ordination and operation of water resource projects. The study focused on water projects aimed at individual household water connection, public stand pipe, borehole, protected dug well, protected springs and rain water harvesting in rural households in Njoro Sub-county. The study has given insight on the extent to which gender disparities occur in management of water resource projects in the district. This will enable formulation of possible measures that can ensure adequate involvement of both men and women in management of water resource projects hence addressing sustainability, effectiveness and efficiency of water resource programmes and projects (Aluka,2006). Adequate supply of clean water is the most important precondition for sustainable development of the water resource. Improving access to quality and quantity water can significantly contribute to sustainable livelihoods as water needs extend beyond the domestic to include other uses such as construction, sanitation, food production, livestock rearing and a wide range of informal micro-enterprises. Targets, such as vision 2030 and Millennium Development Goals of providing greater access to clean drinking water are unlikely to be achieved unless gender related issues are integrated into water project planning and implementation activities (GoK, 2002).

\subsection{Factors Affecting Gender Involvement in Decision Making}

In many instances, gender relations and project procedures account for women having fewer opportunities than men to participate in discussions and decisions, in-spite of their roles as users and managers of water (Suda, 2000; Katui-Katua, 2004; Were et al., 2006). Underlying these are strategic constraints on womens restrictions in autonomy over access to and control over resources, independent choices in decision making, equitable division of rights, domestic and public roles. This may prevent participation of men and women at all levels of project planning and management. According to Vernooy, (2006) the exclusion of women in decision making not only delays delivery of benefits but also affects equity and institutional efficiency.

However, there is little consensus within the literature on whether project policies ensure gender equity advocacy. While this study recognizes the importance of equal representation and participation which encourages independent choices in decision making hence increase efficiency and sustainability of projects. Therefore the need to focus on representation of gender in activities of planning and implementation as there is need to increase the scope for negotiating and bargaining women's interest within the community-level resource use and management.

\section{Implication of Gender in Water Resources Management}

The overall effect of water conservation and demand management should be of overall benefit to all members of society. Some of the mechanisms used to manage water demand can have detrimental effects on women's daily activities. For instance water pricing led to economizing of water use and reduce water wastage leading to the concept of water as a basic human need tends to be overshadowed by the idea of water as a commodity (UNDP, 2004). However pricing of water has several gender specific implications, for instance women tend to have more limited access to monetary than men, similarly women income is more likely to be earmarked for different forms of expenditure than men. Though women and men do some extent pool and share money, but again this is generally biased against women, so that they tend to have restricted access to money (Sokile and koppen). A high pricing of water can be difficult to especially poorer women from access to improved water supply for basic hygiene, consumption and food production. In the drinking water sector, properly designed stepped tariffs can help to subsidize poor households of the community, but there is a danger that less discriminating pricing mechanisms such as water rationing and intermittent supplies will 
further marginalize women. Such mechanisms frequently lead to long queues.

\subsection{Water Sector and Gender Issues}

The assumption that, "both women and men will benefit equally" is false. The division of labour and responsibilities (who does what work), social attitudes, and unequal access to resources all contribute to a situation where policies and programmes have a different impact on women and men, (for example, education initiatives and poverty reduction strategies). Furthermore, these differences and inequalities influence how women and men participate in and respond to new initiatives. (Poku, 2006). In most African societies men's and women's situations, interests, and priorities are different not because of biological differences, but because society's conception of male and female roles and qualities positions of the two groups in a specific relationship to one another. Another underlying root cause of different priorities of men and women in relation to water and sanitation programmes is the low value which is placed on women's time (Department of Water, 1999). Women have traditionally been assigned most of the domestic roles, such as cooking, disposing human waste, drawing water etc. to the point that their public life is severely limited (DFID, 2002). Their narrowed public life is further restricted since men hold positions of authority. In Njoro sub county women are still regarded as in subordinate due to the cultural prejudices as men are regarded as the heads of the households and make major decisions in the household level and community level.

\subsection{Gender in the Different Water Sectors}

In the development and management of water resources it is still rare for implementing organizations and programme staff to ask who requires water for what purposes at household or community level, and what effects demand regulating measures and management structures have on these uses and user groups (Suda, 2000). For many years programmes dealing with irrigated agricultural, domestic water supply, environmental sanitation and industrial development have seen the household as the lowest homogeneous unit of production consumption and decision making. Yet in most cultures men and women, often supported by children, do different work, have different access to resources and different areas in which they can make decisions and exercise control over resources and benefits (UNDP, 2004).

When water projects are undertaken, those involved are generally male staff and male local authorities. Local institutions in which women are present, such as women's organizations, church groups and schools are seldom involved in contacts between projects staff and village authorities. Channels used for information and communication, such as public meetings and written materials are also male-oriented. Women cannot attend public meetings as easily as men and if they can, they have to stay on the edge and keep silent (Department of Water,1999) . They also have less access than men to written information because of the lower proportion of literate women and lower knowledge of official languages. As a result the knowledge and expertise of women, which differs from that of men because of their different tasks, cannot play a role and its value is not acknowledged (Situma, 2000). Projects which assume that information and communication with women can take place through men do not recognize that in many cultures each group has their own channels and topics of communication and hence information and consultation of the women will not take place (Van Wijk, 1995). Women are often the ones most motivated to establish and maintain an improved water supply, yet do not necessarily participate in decisions and management. In a women's dance the women in Misalai, Tanzania, expressed their dissatisfaction over a drinking water supply project, which had failed to bring water to all parts of the village (Machibya, 2003). The community had volunteered to dig the trenches and women had turned up in much higher numbers than men. But when the pipes were finally laid and the water had been connected, it went only to the part of the village where the government leaders were living. The women criticized this result and said that unless the issue was solved they would no longer turn up for volunteer development work (GWA, 2003).

In most societies, women have primary responsibility for management of household water supply, sanitation and health. Water is necessary not only for drinking, but also for food production and preparation, care of domestic animals, personal hygiene, care of the sick, cleaning, washing and waste disposal. Because of their dependence on water resources, women have accumulated considerable knowledge about water resources, including location, quality and storage methods. However, efforts geared towards improving the management of the world's finite water resources and extending access to safe drinking water and adequate sanitation, often overlook the central role of women in water management (Kweka, 1998).

Where good water is scarce and men and women need it for different purposes, such as household uses and cattle, competition and conflicts over its division are common. Examples are livestock areas in Botswana, northern Tanzania and Gujarat and areas with a high fluoride content in groundwater which damages teeth and bones of humans and animals (Kweka,1998). Conflicting interests in water and land use in the catchment areas of community water supply systems also have an increasing negative impact on the availability and quality of drinking water. 


\subsection{Gender Aspects and Water Policy and Rights}

In many cases water resource policies and programmes have proven detrimental to women's water rights and, therefore, to their sustainable management and use of water. Interventions such as irrigation habitually fail to take into consideration the existing imbalance between men's and women's ownership rights, division of labour and incomes. By raising the value of the land, irrigation brings about social change which usually favours men. Irrigation systems also tend to favour mono-cropping, often for the production of cash crops, and thus may exclude provisions for a more diversified cropping pattern supporting a variety of food crops. As cash crops are usually controlled by men, decisions regarding the scheduling of irrigation water tend to be made without consideration for women's farm and household activities (GWA, 2003). Women play an important role in water management. They are most often the collectors, users and managers of water in the household as well as farmers of irrigated and rain-fed crops. Because of these roles, women have considerable knowledge about water resources, including quality and reliability, restrictions and acceptable storage methods, and are input to the success of water resources development and irrigation policies and programmes, (Aluka,2006).

Gender has been consistently translated in policy into the involvement of women in water projects; (Gok, 2010).When viewed against the backdrop of women's earlier exclusion from involvement in projects, evidence of their inclusion is partially encouraging. Reports include women learning new skills - from basic literacy and numeracy to plumbing and masonry, being involved in decision making regarding water management, receiving new respect in their homes and communities and turning water projects into income generating projects, (Cleaver and Kessler 1998). Particular emphasis has been given to the need to base water development and management on a participatory approach, involving users, planners and policy-makers at all levels.

\section{Research Design}

The study employed a descriptive survey research design. According to Mugenda and Mugenda, (1999) survey involves studying a situation, as it is in an attempt to explain why the situation is the way it is. Surveys, according to Kathuri and Pals (1993) are important in research and have been found to be useful in describing the characteristics of a population under study. They are cost effective and exploratory enabling the researcher to make inferences into the level of cause and effect (Mugenda and Mugenda, 1999). The study was conducted in Njoro Sub-county in Nakuru County. The Sub-county was selected because there was widespread scarcity and gradual destruction of water resource in the region and the need for provision of water could have a catalytic effect through time saving and introduction of new skills which give gender the chance for more productive activities. The Sub-county is served by one major river, Njoro and several seasonal streams and springs which drain in lake Nakuru, the region also has individuals and communal protected borehole. Sample households and water projects were obtained from Njoro division, Lare division, Kihingo division, Mau Narok division. Sample Size and Sampling Procedure Four of the five divisions of the district were sampled. The fifth division (Mauche) was avoided as it is a settlement on government forest and the government has given indication on repossessing it. From the total 42 water projects, 21 projects were proportionately sampled from the 4 divisions. From the selected water projects a sample size of 120 household units were selected through stratified random sampling. The data was collected using semi-structured interview schedule which were administered to the respondents. The data generated from the study was analyzed by descriptive and inferential statistics. Data related to the demographic characteristic of the applicants namely age, households' heads, household's size, level of education, gender, water source and land size which were analyzed descriptively. Inferential Statistics was analyzed at 5\% level of significance and included: chi-square. Chi-square was used to analyze and interpret categorical data.

\section{Results}

Demographic characteristics of the respondents indicate that most respondents across the four divisions were males $64.2 \%$ while $35.8 \%$ were females. On average $2.4 \%$ of the respondent's ages ranged between $21-30$ years, $24.2 \%$ ranged 31-40 years, while $41-50$ years were $61.7 \%$ and those above 50 years were $11.7 \%$. This is an indication of engagement of both young and old in water resource management hence a great variation in household age data. In the Sub-county, $55 \%$ of the respondents had between 3-6 dependents, while $30.8 \%$ of the respondents had $7-9$ and $14.2 \%$ of the respondent had 10-12 dependants. From the demographic data it can be concluded that in Njoro Sub-county the Males are dominant than women which may have an impact during voting for leadership positions in the management level of water projects. Also the gender imbalance may affect the women's view, interests and needs and hence influence the way in which duties, benefits and responsibilities in water projects are divided between women and men of different age groups, classes and socio-economic status. 


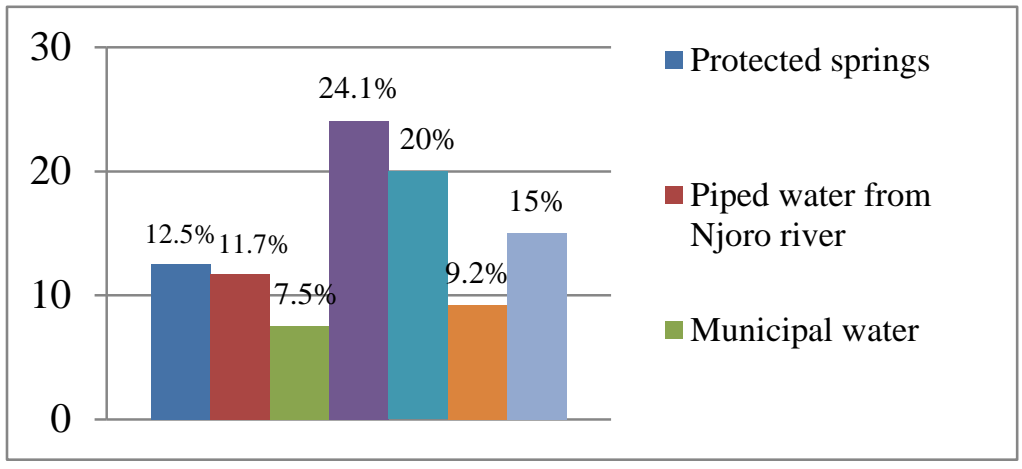

Source: Field Data, 2010

Figure 4.1 Water Source in Njoro Sub-county

In the Njoro Sub-county there were several water sources which supplied water and are represented in figure 4.1. From the responses $12.5 \%$ of the respondents utilized protected springs, $11.7 \%$ piped water from Njoro river, $7.5 \%$ municipal water, $24.1 \%$ community borehole with kiosks, $20 \%$ community borehole with individual connections, $9.2 \%$ rain water harvesting using sand dams and $15 \%$ rain water harvesting using tanks. Households not connected with pipe water pose a risk of drinking untreated water from open wells or surface waters. The main risk of the use of untreated water might be the incidence of some water related diseases in the area. Depending on the source women in Njoro Sub-county face the challenge of walking long distances to draw the water or make long queues waiting to fetch the water. This narrows down the public life of women restricting women to participate in the public activities.

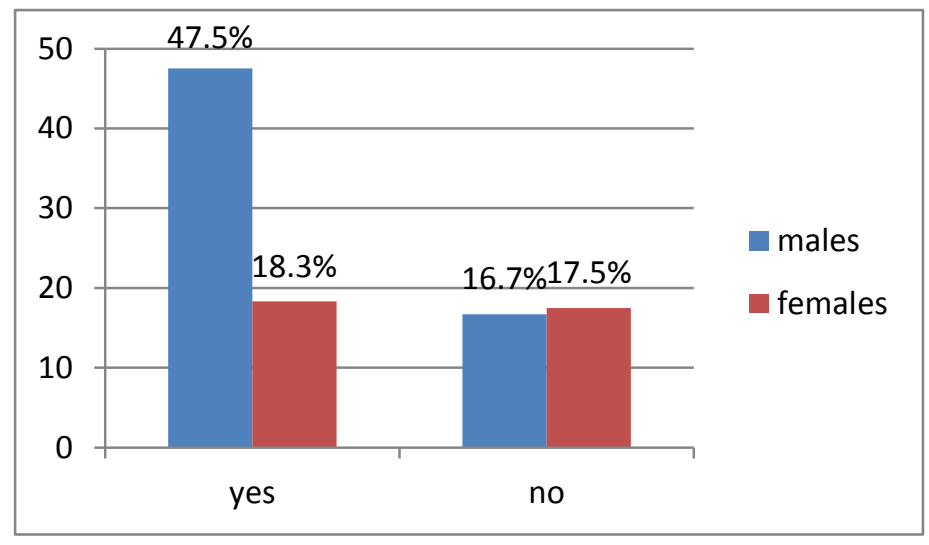

Source: Field Data, 2010

Figure 4.2 Gender involvement in Management of Water Projects

Gender involvement in the management of water projects is indicated on figure 4.2. In the management of water projects $47.7 \%$ males participated compared to $18.3 \%$ females. This indicates that males dominated in the management of water projects than females. It can be conclude that due to the women's domestic roles such as cooking, disposing human waste, drawing water their public life is severely limited. As a result of this they cannot attend meetings where democratic elections are conducted.

Table 4.1 Hindrance of Gender Participation in Water projects

\begin{tabular}{|c|c|c|c|c|c|c|c|c|}
\hline \multirow{2}{*}{ Hinderance } & & \multicolumn{2}{|c|}{ Males } & \multicolumn{2}{|c|}{ Females } & \multirow[b]{2}{*}{ value } & \multirow[b]{2}{*}{$\mathrm{df}$} & \multirow[b]{2}{*}{$\mathrm{p}$} \\
\hline & & Freq & $\%$ & Freq & $\%$ & & & \\
\hline Education & Yes & 32 & 26.7 & 23 & 19.2 & 1.538 & 1 & 0.143 \\
\hline level & No & 45 & 37.5 & 20 & 16.7 & & & \\
\hline Timing & Yes & 34 & 28.3 & 29 & 24.2 & 1.348 & 1 & 0.012 \\
\hline meetings & No & 43 & 35.8 & 14 & 11.7 & & & \\
\hline Awareness of & Yes & 31 & 25.8 & 27 & 22.5 & 1.268 & 1 & 0.176 \\
\hline meetings & No & 46 & 38.3 & 16 & 13.3 & & & \\
\hline Cultural & Yes & 6 & 5 & 24 & 20 & 1.568 & 1 & 0.134 \\
\hline customs & No & 71 & 59.2 & 19 & 15.8 & & & \\
\hline
\end{tabular}

Source: Field Data, 2010 
The results in table 4.1 show the relationship between gender and hindrance in participation in water projects. Level of education, awareness of meetings, cultural customs and timing of meetings were highlighted as the major hindrance in participation. There is statistical significance between gender and each hindrance. This variability in the findings can be explained by the fact that channels used for information and communication is written materials in which many women had a problem to read and when they attend meetings they stay at the back of the congregation as the cultural customs do not allow them to sit in front and keep silent. Time is the key resource in women's strategies to participate, yet most rural women have insufficient time. A heavy work burden leaves women little time to participate in planning and implementation of water resource projects. The drudgery of rural women's work due to cultural customs raises gender equality considerations concerning rural women and their efforts to improve water supply in the households.

\section{Conclusions}

From the results women participate in project activities, discussions and decision making is very low hence not meeting their practical gender needs. From the findings women are still bound by traditional expectations and roles. Despite the government enacting the constitution encouraging a third of either gender in management of public institutions projects in Njoro sub-county still face gender disparities. In most of the cases the water resources policies and programmes at the grass roots level do not take in account the regulation of a third rule hence affecting sustainable management of the water projects leading to water shortage at household level. From the study women play a dominant role in management of water at user level and not at management level due to various hindrances such as level of education, cultural customs among others which affect their communication and participation.

\section{Recommendation}

Considering that women have knowledge about water resources including quality and reliability of the water source water projects should engage gender expert before initiating a water project to advice on how to entrench the gender issues in planning and implementing the projects. Affirmative action campaign on women to have equal say should be encouraged through formation of women groups which should initiate projects aimed at rain water harvesting at household level. Water policies and programmes should include women's rights due to the fact that women manage the household well and they too can make good decisions, but women are still bound by traditional expectations and roles.

\section{References}

Alouka, S. (2006). Integrating Gender into the Promotion of Hygiene in Schools. In: Office of the Special Adviser on Gender Issues and Advancement of Women, Gender, water and sanitation: case studies on best practices. New York, United Nations.

Cleaver, F., \& Kaare, B. (1998). Social embeddedness and project practice: A gendered analysis of promotion and participation in the Hesawa Programme, Tanzania, And Bradford: University of Bradford for Sida.

Cleaver, F., \& Elson, D. (1995). Women and Water Resources: Continued Marginalization and New Policies, London, International Institute for Environment and Development, Gatekeeper Series, 49.

Department of water. (1999). National Policy on Water Resources Management and Development. Sessional paper No.1 Nairobi Ministry of Environment and Natural Resources, 14.

DFID. (2002). Gender issues in the Management of Water Projects. Available at: http://www.wateraid.org/documents/g_gender_issues.pdf Accessed on November 2010

Gender and Water Alliance (GWA). (2003). Gender Perspectives on Policies in the Water.Available at: http://www.genderandwater.org Accessed on November 2010

Government of Kenya. (2002). The Water Bill, 2002. In Kenya Gazette Supplement, Bills 2002, Government Printer: Nairobi, 287-413.

Government of Kenya. (2010). Central Bureau of Statistics, Annual Report Nakuru District, Central Bureau of Statistics.

Green, C., \& Baden, S. (1994). Water Resources Management: A Macro-level Analysis report,Washington, D.C.

Kathuri, N. J., \& Pals, D. A. (1993). Introduction to Educational Research, EMC, Njoro.

Katui-Katua, M. (2004). Drawers of Water II: Kenya Country Report, International Institute for Environment and Development: London.

Kweka, R. (1998). Women in Smallholder Irrigation in Tanzania, In: Gender Analysis andReform of Irrigation Management, Concepts, Cases and Gaps in Knowledge. Tanzania, International Water Management Institute.

Machibya, M. (2003). Challenging Established Eoncepts of Irrigation Efficiency in a Water Scarce River Basin: a case 
study of the Usangu basin, Tanzania. PhD thesis, University of East Angila.

Mugenda, O. M., \& Mugenda, A. G. (1999). Research methods: Quantitative and Qualitative approaches Nairobi, Kenya: acts Press.

Poku, S. (2006). Ghana: Gender Integration in a Rural Water Project in the Samari-Nkwanta Community. In: Office of the Special Adviser on Gender Issues and Advancement of Women, Gender, water and sanitation: case studies on best practices. New York, United Nations.

Situma, M. (2000). Environmental Problems in Kenya. Konard Adenauer Foundation. Nairobi: Kenya.

Sokile, C. S., \& van Koppen, B. (2003). Local Water Rights and Local Water User Entities: the Unsung Heroines to Water Resource Management in Tanzania. A paper presented at the WATERNET/WARFSA 4thd Symposium. Gaborone, Botswana, October 2003.

Suda, C. (2000). Gender, culture and environmental conservation in Western Kenya: contextualizing community participation and the choice of techniques. Nordic Journal of African Studies, 9(1), 31-48.

United Nations Development Programme (UNDP), (2004). Gender and Energy for Sustainable Development: A Toolkit and Resource Guide. New York.

United Nations Development Programme (UNDP). (2002). Dialogue on Effective Water Governance Available at: http://www.undp.org Accessed on November 2013.

Van Wijk-Sijbesma, C. (1995). Gender in Community Water Supply, Sanitation and Water Resources Protection: A Guide to Methods and Techniques, IRC International Water and Sanitation Centre, The Hague.

Vernooy, R. (ed.). (2006). Social and Gender Analysis in Natural Resource Management, Learning Studies and Lessons from Asia Sage India/CAP/IDRC 2006. http://www.idrc.ca/en/ev-91907-201-1-do_topic.

WHO/UNICEF. (2004). Coverage Estimates, Improved Drinking Water, Kenya. World Health Organization/United Nations Children's Fund, Joint Monitoring Program for Water Supply and Sanitation,Geneva,Switzerland; http://www.wssinfo.org/en/welcome Accessed on November 20130.

Women's Environment and Development Organization (WEDO), (2003). Untapped Connections: Gender, Water and Poverty: Key Issues, Government Commitmentsand Actions for Sustainable Development, New York: WEDO.

This work is licensed under a Creative Commons Attribution 3.0 License. 